\title{
Differences in the antigenic expression of immunomodulatory mannoprotein constituents on yeast and mycelial forms of Candida albicans
}

\author{
antonella Torosantucci, Maria Boccanera, ida Casalinuovo, Guido Pellegrini and \\ ANTONIO CASSONE*
}

Laboratory of Bacteriology and Medical Mycology, Istituto Superiore di Sanità, Rome, Italy

(Received 11 October 1989; revised 12 February 1990; accepted 20 March 1990)

\begin{abstract}
The expression of a strongly immunomodulatory mannoprotein complex (GMP) in the different forms of growth of the human commensal and opportunistic pathogen Candida albicans was studied using a monoclonal antibody (mAb AF1) directed against an oligosaccharide epitope of GMP. Immunofluorescence revealed that the surface of the yeast cells was highly reactive with $\mathrm{mAb} A F 1$, but that the reactivity was greatly reduced or disappeared during mycelial conversion. This modulation was shared by a number of strains of $C$. albicans, and was not solely a temperature- or nutrition-dependent phenomenon. Hypha-deficient strains (A12 and CA2) did not show variations of surface fluorescence under environmental conditions which were permissive for hyphal conversion (incubation in $\mathrm{N}$-acetylglucosamine or Lee's medium, at $37^{\circ} \mathrm{C}$ ). GMP extracts from yeast and mycelial forms of the fungus were separated into three chromatographically distinct, high molecular mass mannoprotein fractions (F1, F2 and F3), which were tested individually by indirect ELISA for $\mathrm{mAb}$ AF1 recognition. All yeast-derived constituents and two (F2 and F3) of the hyphal mannoproteins were recognized by the mAb. The low or absent reactivity of the F1 constituent from hyphal cells was confirmed by immunoblots. Irrespective of their source (yeast or mycelial), all fractions reacted to a similar extent with a polyclonal anti-Candida serum. Overall, the data suggest changes in epitope specificity and/or confinement of reactive constituents in the inner wall layers as possible mechanisms of modulated expression of mAb AF1-reactive epitope during mycelial conversion.
\end{abstract}

\section{Introduction}

Cell wall mannoproteins of Candida albicans play an important role in the host-parasite relationship. They are major cellular antigens, mediate adhesion of the micro-organism to host cell surfaces, and some of them are virulence enzymes (Odds, 1987; Domer et al., 1988; Cassone, 1990). Recent studies have demonstrated remarkable changes in the surface expression of these molecules during fungal growth and morphogenesis (Poulain et al., 1985). In particular, antigenic determinants exclusively or predominantly expressed on the yeast or hyphal form of growth have been found (Smail \& Jones, 1984; Brawner \& Cutler, 1986; Sundstrom et al., 1988; Chaffin et al., 1988; Casanova et al., 1989). Modulation of antigen expression may provide the fungus with a potent means to evade the host's immune response or minimize its consequences. It is possible that the pathogenic value of this mechanism is proportional

Abbreviations: mAb, monoclonal antibody; M-GMP, Y-GMP, glucomannan preparations from mycelial and yeast cells, respectively. to the importance that the modulated molecule has in eliciting an efficient immune response by the host. In this context, the aforementioned studies did not establish the immunological or pathogenic role, if any, of the molecules whose expression was modulated. Thus, we sought for possible modulations in the expression of antigenic constituents of a mannoprotein complex (GMP) of $C$. albicans that had been shown to have powerful immunogenic and immunomodulatory activities (Cassone et al., 1987; Scaringi et al., 1988; Ausiello et al., 1989).

\section{Methods}

Organisms and growth conditions. All strains of C. albicans used in this study were from the collection of the Istituto Superiore di Sanità, Rome. Unless otherwise specified, experiments were performed with strain BP. Details of the origin and characteristics of this strain and of the two agerminative variants (CA2 and A12) used have been given elsewhere (Mattia et al., 1982; Torosantucci et al., 1984). Methods for isolation and characterization of $C$. albicans, including serotype determination, were as previously reported (Mondello et al., 1986). 
The organisms were maintained on malt-extract agar. Liquid, yeastform cultures were grown in Winge medium (Torosantucci et al., 1984) at $28{ }^{\circ} \mathrm{C}$. Growth in the mycelial form was induced by incubating washed, stationary-phase yeast cells in $\mathrm{N}$-acetylglucosamine (GlcNAc) or modified Lee's medium, at $37^{\circ} \mathrm{C}$ (Lee et al., 1975; Torosantucci et al., 1984). In GlcNAc medium, germ-tubes were microscopically visible after $60-90 \mathrm{~min}$ of incubation, and more than $90 \%$ of the original yeast cells bore one or two hyphal elements after $240 \mathrm{~min}$. Agerminative variants $\mathrm{A} 12$ and $\mathrm{CA} 2$, under the same cultural conditions, produced no germ-tubes, and continued to grow in the yeast form.

Preparation of cell wall mannoprotein complex $(G M P)$ of C. albicans. A glucomannoprotein preparation, containing a major cell wall antigenic complex of the fungus, was obtained as previously reported (Ausiello $e t$ al., 1986; Scaringi et al., 1988), from both yeast (Y-GMP) and hyphal (M-GMP) cells. Yeasts were grown for $24 \mathrm{~h}$ at $28^{\circ} \mathrm{C}$ in Winge broth, while hyphal cells were obtained from $24 \mathrm{~h}$ cultures in GlcNAc medium at $37^{\circ} \mathrm{C}$ (see above). The two antigenic preparations contained comparable amounts of polysaccharides and slightly different amounts of protein, as determined by the phenol/sulphuric acid method of Dubois et al. (1956) and by Lowry's method, respectively (see also Table 2 ).

DEAE-Sephadex chromatography. Y-GMP and M-GMP were fractionated in a $16 \times 1 \mathrm{~cm}$ column of DEAE-Sephadex A50 (Pharmacia), pre-equilibrated with $0.05 \mathrm{M}-\mathrm{Tris} / \mathrm{HCl}$ buffer, $\mathrm{pH} 7.5$. Ten milligrams of each antigenic preparation was loaded on the column and, after extensive washing with buffer, bound material was eluted with a linear gradient $(0-2 \mathrm{M})$ of $\mathrm{NaCl}$.

The eluate was collected as $1.5 \mathrm{ml}$ fractions and assayed for total polysaccharide and for absorbance at $260 / 280 \mathrm{~nm}$. Peak fractions were pooled and either dialysed against $0.2 \mathrm{M}$-sodium carbonate for use in the ELISA or dialysed against $\mathrm{H}_{2} \mathrm{O}$, lyophilized and resuspended at a suitable concentration for immunoblot analysis.

Antibodies. mAb AF1 was a murine monoclonal antibody of the IgM class raised against Y-GMP (Cassone et al., 1988). Anti-Candida serum was obtained in rabbits after subcutaneous immunization with glutaraldehyde-inactivated cells of C. albicans (Scaringi et al., 1988). Both antibodies were purified by ammonium sulphate precipitation or by affinity chromatography on a Protein A-Monoclonal Antibody Purification System (MAPS II), as reported elsewhere (Mariani et al., 1989).

Antibody titres were determined as the highest dilution of the antibody giving at least twice the absorbance value of the negative control (irrelevant antibody) in an indirect ELISA (see below), employing Y-GMP $\left(5 \mu \mathrm{g} \mathrm{ml}^{-1}\right)$ as solid-phase antigen.

ELISA. Antigenic fractions were diluted to different polysaccharide concentrations in $0.2 \mathrm{M}$-sodium carbonate buffer, $\mathrm{pH} 9 \cdot 6$. The solutions were dispensed into 96-well polystyrene microtitre plates (Dynatech), at $200 \mu \mathrm{l}$ per well, and incubated overnight at $4{ }^{\circ} \mathrm{C}$. Antigen solutions were then removed, the wells were saturated for $1 \mathrm{~h}$ at room temperature with $3 \%(\mathrm{w} / \mathrm{v})$ bovine serum albumin (Sigma) and repeatedly rinsed with $0.2 \mathrm{M}$-phosphate-buffered saline (PBS) containing $0.05 \%$ Tween 20 . Antibody $(200 \mu \mathrm{l})$, diluted to the desired concentration in PBS, was subsequently added to the wells, and the plates were incubated for $1 \mathrm{~h}$ at room temperature. After several washings with PBS-Tween 20, antigen-bound antibody was revealed by adding goat anti-mouse IgM- or goat anti-rabbit IgG-alkaline phosphatase conjugates (Sigma) for $1 \mathrm{~h}$, then $p$-nitrophenyl phosphate ( $1 \mathrm{mg} \mathrm{ml}^{-1}$ in $1 \mathrm{M}$-diethanolamine $\left./ \mathrm{HCl}, \mathrm{pH} 9.8\right)$. The reaction was stopped after $20 \mathrm{~min}$ by adding $40 \mu \mathrm{l} 3 \mathrm{M}-\mathrm{NaOH}$. Plates were read with a Titertek Multiscan set at $405 \mathrm{~nm}$. Readings of the ELISA were calculated as means of triplicate determinations; the SD values were always less than $0 \cdot 1 \%$ and have been omitted from the results. $A_{405}$ values of negative control wells (i.e. wells coated with the highest concentration of the solid-phase antigen and reacted with an irrelevant antibody) were considered as the 'background reading' and subtracted from the results. A positive reaction was assumed when $A_{405}$ values were more than twice the 'background reading' (usually 0.14-0.18).

Agglutination assay. The ability of purified mAb AF1 to agglutinate yeast cells of several Candida strains was assessed as reported elsewhere (Cassone et al., 1988). Briefly, yeast cells were grown for $24 \mathrm{~h}$ in Winge medium at $28^{\circ} \mathrm{C}$, washed, then adjusted to a concentration of $3 \times 10^{7}$ cells $\mathrm{ml}^{-1}$ in saline; $25 \mu \mathrm{l}$ of this cell suspension were mixed with $25 \mu \mathrm{l}$ of affinity-purified mAb AFl, at appropriate dilutions, on an agglutination slide, which was gently agitated for 5-10 min at room temperature. The results were assessed visually and expressed as endpoint of antibody dilution giving clearly visible clusters of cells. Positive and negative controls were included in the test (see also Cassone et al., 1988).

Indirect immunofluorescence. Yeast cells of $C$. albicans were induced to germinate in GlcNAc or Lee's medium (see above), and at different incubation times (up to $24 \mathrm{~h}$ ), cells were harvested, resuspended in PBS and heat-fixed $\left(30 \mathrm{~min}, 60^{\circ} \mathrm{C}\right)$ on a microscope slide. The smears were covered for $30 \mathrm{~min}$ at $37^{\circ} \mathrm{C}$ with the antibody (mAb AFl or polyclonal rabbit antibody, each used at concentrations 1 and 5 times their previously established immunofluorescence titres), washed twice in PBS and allowed to react for $30 \mathrm{~min}$ at $37^{\circ} \mathrm{C}$ with fluorescein isothiocyanate (FITC) conjugated to goat anti-mouse IgM or antirabbit IgG (Sigma). After extensive washing with PBS, the slides were mounted in $0.2 \mathrm{M}$-sodium carbonate buffer, pH 9.0, containing $90 \%$ (v/v) glycerol and examined by fluorescence microscopy (SM-LUX, Leitz).

Morphology control experiments were also performed with yeast cells of germinative strains incubated in GlcNAc medium at $28^{\circ} \mathrm{C}$ (a germ-tube non-permissive temperature) or with cultures of the two agerminative variants, CA2 and A12 (Torosantucci et al., 1984), in the same medium, at $37^{\circ} \mathrm{C}$.

Immunoblot assay. Antigenic fractions were subjected to SDS-PAGE according to Laemmli (1970), in a Mini-Protean II electrophoresis cell (Bio-Rad), using a $5-10 \%(\mathrm{w} / \mathrm{v})$ acrylamide gradient slab, $0.75 \mathrm{~nm}$ thick, as the running gel and a $3.5 \%$ acrylamide as stacking gel. Twenty microlitres of each sample, at a polysaccharide concentration of $1 \mathrm{mg} \mathrm{ml} \mathbf{m}^{-1}$, was run at a constant voltage of $200 \mathrm{~V}$ for approximately $45 \mathrm{~min}$ and subsequently transblotted for $1 \mathrm{~h}$, at a constant voltage of $100 \mathrm{~V}$, onto a nitrocellulose paper sheet (Bio-Rad) in $0.025 \mathrm{M}$ Tris/0.192 M-glycine buffer, pH 8.3, containing $20 \%$ (v/v) methanol.

For immunological detection, the nitrocellulose was treated for $1 \mathrm{~h}$ with PBS containing $0 \cdot 15 \%$ Tween 20 , then incubated overnight at $4{ }^{\circ} \mathrm{C}$ with an appropriate dilution of mAb AF1 in PBS-Tween 20. After several washings in PBS, the bound $\mathrm{mAb}$ was revealed by treating the nitrocellulose sheet with an alkaline phosphatase-conjugated antimouse IgM antibody (Sigma), at 1:1000 strength, followed by FastRed/naphtholphosphate colour development solution (Bio-Rad) as the enzyme substrate.

\section{Results}

\section{Expression of $m A b$ AF1-reactive epitope on the surface of yeast and mycelial cells}

Immunofluorescence was used to study the binding of mAb AF1 to yeast and mycelial forms of several strains of C. albicans. Control experiments were performed with 

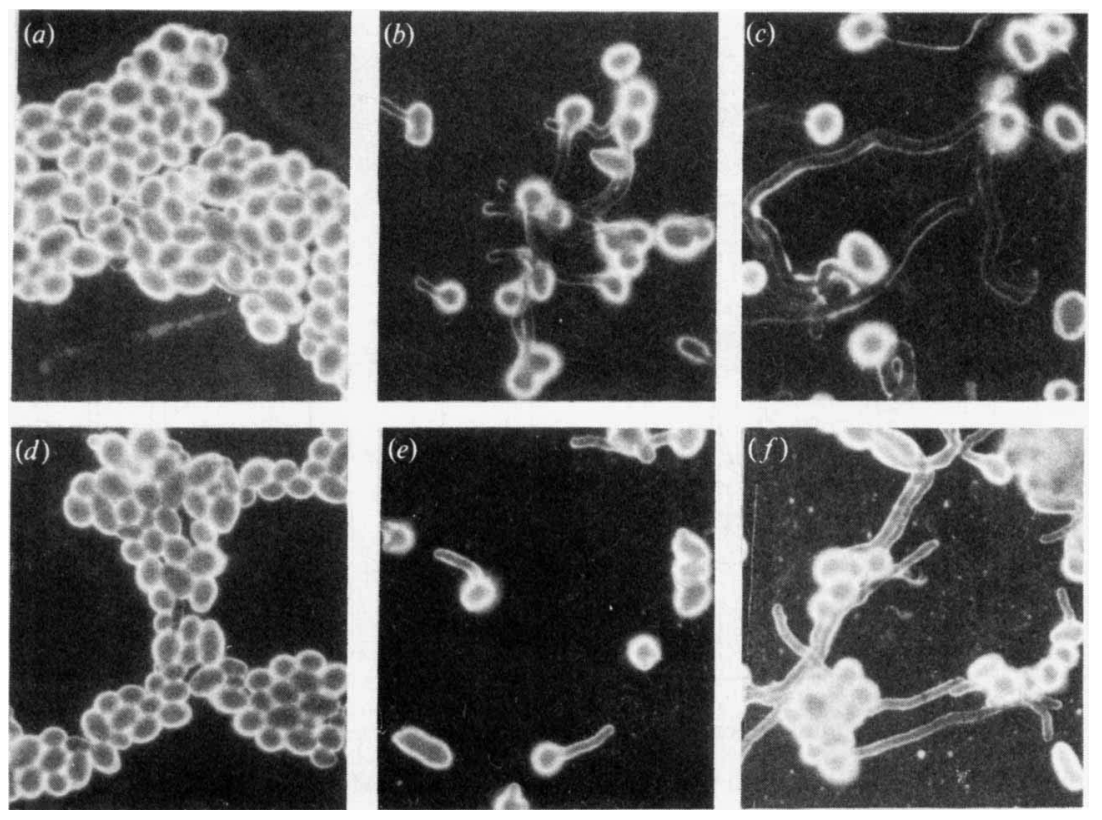

Fig. 1. Immunofluorescence pattern of yeast $(a, d)$, germ-tube $(b, e)$ and hyphal $(c, f)$ cells of $C$. albicans after reaction with $\mathrm{mAb}$ AF1 $(a$, $b, c)$ or polyclonal anti-Candida serum $(d, e, f)$. Germ-tubes and hyphal cells were formed by incubating yeast cells in modified Lee's medium for $120 \mathrm{~min}$ (germ-tubes) and $24 \mathrm{~h}$ (hyphal cells). For other details, see text. Magnification $\times 380$.

irrelevant $\mathrm{mAbs}$ and polyclonal anti-Candida serum. Fig. $1(a, b, c)$ shows a typical pattern of immunofluorescence obtained after reaction of $\mathrm{mAb} A F 1$ with yeast and hyphal forms of strain BP of C. albicans.

While the yeasts fluoresced strongly, the hyphal filaments were scarcely or not at all fluorescent. Any fluorescence associated with germ-tubes was usually detected only during the early stages of the morphogenesis while the surface of the mother cell remained stably fluorescent (Fig. 1b). Some fluorescence could be also observed at the hyphal tip (Fig. 1c). This pattern of fluorescence was not influenced by the medium used to obtain hyphal forms (GlcNAc or Lee's medium).

Both yeast and mycelial cell surfaces were constantly fluorescent, although to a slightly different extent, when the polyclonal anti-Candida serum was used (Fig. $1 d, e$, $f$ ). All other germinative strains examined showed a comparable, although quantitatively different pattern of fluorescence, with reproducible differences of reactivity between the yeast and the mycelial form. Table 1 shows the fluorescence intensities and $\mathrm{mAb} A F 1$ agglutination properties of all the strains tested. In only one case $(C$. albicans 195) was the fluorescence intensity roughly similar for yeast and hyphal cells. The most striking difference in fluorescence of the two morphological elements occurred with the isolate 221 . Interestingly, this isolate had the highest agglutinability with mAb AF1 (Table 1).
Table 1. Agglutination and indirect immunofluorescence (IF) reactivity with $m A b A F 1$ of yeast and hyphal cells of C. albicans

IF tests were performed using a 1:50 dilution of a mAb AF1 preparation with an ELISA titre of $1: 2000$. For other details on agglutination and IF test, see Methods.

\begin{tabular}{lcccc}
\hline \hline & & & & \\
& & Fgglutination & & \\
\cline { 3 - 5 } Strain & Serotype & $\begin{array}{c}\text { Fluorescence intensity* } \\
\text { titre }\end{array}$ & Yeast cells & Hyphal cells \\
\hline 237 & A & $1: 25$ & ++ & \pm \\
243 & A & $1: 25$ & +++ & + \\
195 & A & $1: 25$ & +++ & +++ \\
213 & A & $1: 25$ & +++ & + \\
196 & A & $1: 50$ & +++ & + \\
200 & A & $1: 75$ & +++ & + \\
214 & A & $1: 25$ & +++ & + \\
189 & A & $1: 25$ & +++ & + \\
215 & A & $1: 25$ & +++ & \pm \\
BP & A & $1: 25$ & +++ & + \\
3153 & A & $1: 25$ & +++ & + \\
239 & B & $1: 25$ & +++ & + \\
221 & B & $1: 100$ & +++ & + \\
170 & B & $1: 25$ & +++ & ++++ \\
CA2 & A & ND & ++ & ++++ \\
A12 & A & ND & +++ & + \\
\hline \hline
\end{tabular}

ND, Not done.

* IF tests were performed with hyphal cells developed in GlcNAc medium at $37^{\circ} \mathrm{C}$ for $4 \mathrm{~h}$ and with yeast cells kept at $28^{\circ} \mathrm{C}$ for an equivalent time. - , Fluorescence totally absent; \pm , barely detectable fluorescence;,,++++++ , different, arbitrary, scores of increasing fluorescence intensities.

$\dagger \mathrm{CA} 2$ and $\mathrm{A} 12$ are agerminative variants which produced short, pseudomycelial-like filaments in GlcNAc medium at $37^{\circ} \mathrm{C}$. 

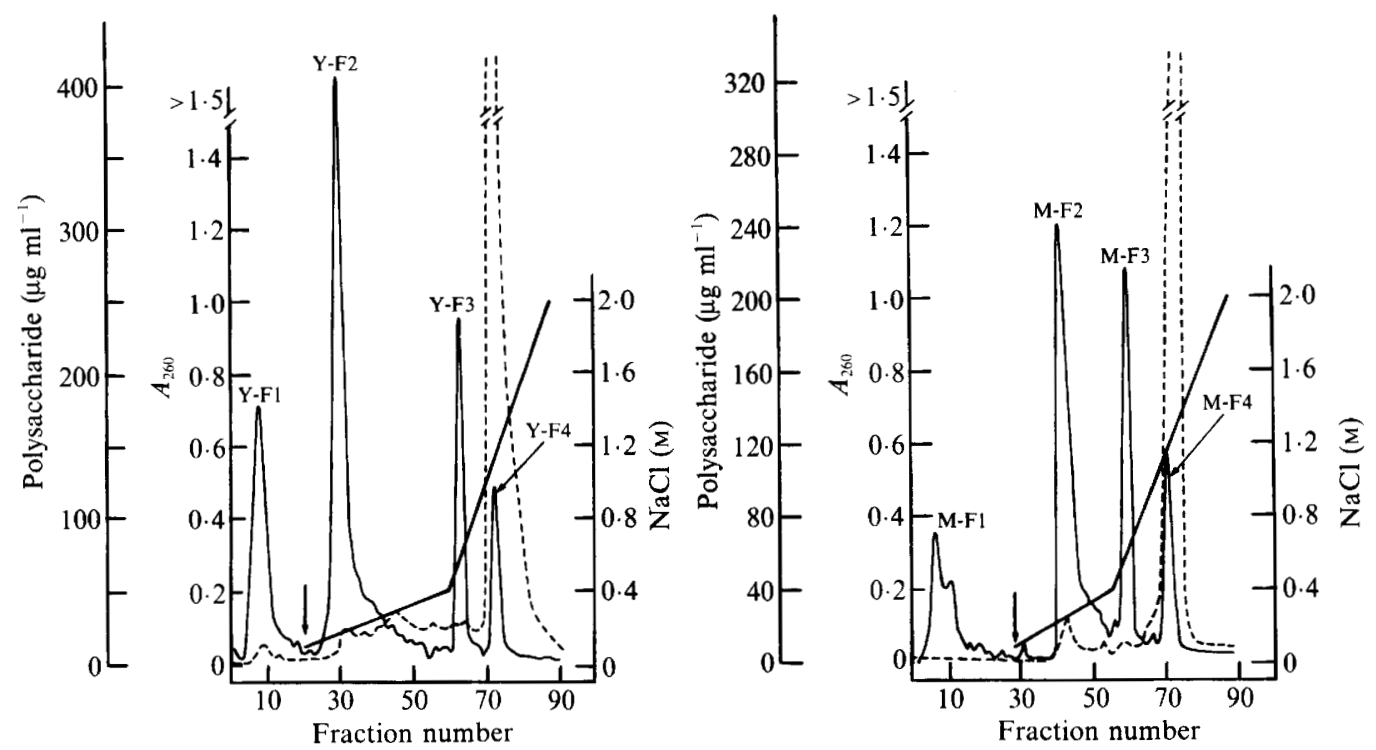

Fig. 2. Chromatographic separation of GMP from yeast (Y-F, left) or mycelial (M-F; right) cells of C. albicans. -

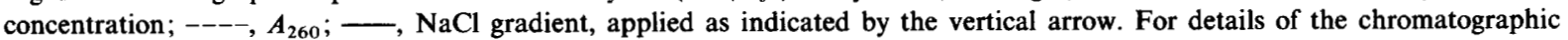
procedure, see Methods.

The simple incubation of yeast cells in buffer either at $28^{\circ} \mathrm{C}$ or $37^{\circ} \mathrm{C}$ (where no germination occurred) did not provoke any change in the pattern of fluorescence of yeast cells. Similarly, yeast cells of two agerminative, mAb AF1-reactive variants (CA2 and A12) were comparably fluorescent at $28^{\circ} \mathrm{C}$ and $37^{\circ} \mathrm{C}$ (Table 1).

\section{Chromatographic separation of mannoprotein constituents}

Mannoprotein preparations from yeast (Y-GMP) and mycelial (M-GMP) cells of $C$. albicans were subjected to ion-exchange chromatography with $\mathrm{NaCl}$ gradient elution (Fig. 2). In both cases, four major peaks were clearly separated, the most abundant of which were the unbound material (fraction $\mathrm{F} 1: 9.6 \%$ and $10.5 \%$ recovery as sugar from Y-GMP and M-GMP, respectively) and fraction $\mathrm{F} 2$, eluted at $0 \cdot 2-0 \cdot 25 \mathrm{M}-\mathrm{NaCl}(39 \cdot 3 \%$ and $39.9 \%$ recovery as sugar from Y-GMP and M-GMP, respectively). These fractions were followed by two sharply separated, minor fractions (F3 and F4). The latter, likely to consist mostly of nucleoprotein material (as shown by its strong absorbance at $260 \mathrm{~nm}$ and high relative phosphorus content; A. Torosantucci and others, unpublished data) was retained for use as a negative control in subsequent studies (see below). Fractions F1, F2 and F3 from both yeast and mycelial cells were essentially composed of mannoprotein material (see also Scaringi et al., 1988), the hyphal fractions having a higher protein content relative to the polysaccharide than the yeast fractions (Table 2).
Table 2. Chemical composition of GMP fractions from yeast and mycelial cells of $C$. albicans

GMP was extracted from yeast $(24 \mathrm{~h}$ growth in Winge medium at $\left.28^{\circ} \mathrm{C}\right)$ or hyphal $\left(24 \mathrm{~h}\right.$ growth in GicNAc medium at $\left.37^{\circ} \mathrm{C}\right)$ cells. The analytical values are expressed as $\mu \mathrm{g}$ per $\mathrm{mg}$ cell dry weight.

\begin{tabular}{|c|c|c|c|c|c|c|}
\hline \multirow[b]{2}{*}{ Fraction } & \multicolumn{3}{|c|}{ Yeast cells } & \multicolumn{3}{|c|}{ Hyphal cells } \\
\hline & Sugar & Protein & $\begin{array}{c}\text { Protein/ } \\
\text { sugar ratio }\end{array}$ & Sugar & Protein & $\begin{array}{c}\text { Protein/ } \\
\text { sugar ratio }\end{array}$ \\
\hline GMP & $4 \cdot 50$ & 0.41 & 0.09 & 4.96 & 0.63 & $0 \cdot 13$ \\
\hline $\mathrm{F} 1$ & 0.43 & 0.01 & 0.02 & 0.52 & 0.02 & 0.04 \\
\hline $\mathrm{F} 2$ & 1.77 & 0.09 & 0.05 & 1.98 & $0 \cdot 16$ & 0.08 \\
\hline F3 & 0.11 & ND & - & 0.09 & ND & - \\
\hline F4 & 0.60 & 0.06 & $0 \cdot 10$ & 0.57 & 0.09 & 0.16 \\
\hline
\end{tabular}

ND, not done.

mAb AFI reactivity with individual mannoprotein fractions

Mannoprotein fractions were tested for their antigenic reactivity with $\mathrm{mAb} A F 1$ and with the polyclonal serum raised against whole, chemically inactivated, cells of $C$. albicans. The reactivity was measured by indirect ELISA and, in the case of mAb AF1, by Western blotting (immunoblotting). Fig. 3 compares the reactivity of yeast and mycelial mannoprotein fractions in ELISA using a fixed amount of mAb AF1 and different concentrations of each fraction tested as coating antigen (within the range $0 \cdot 2-1 \cdot 0 \mu \mathrm{g} \mathrm{ml}^{-1}$ ). The unfractionated mannoprotein extract (GMP) was also assayed. Although with 

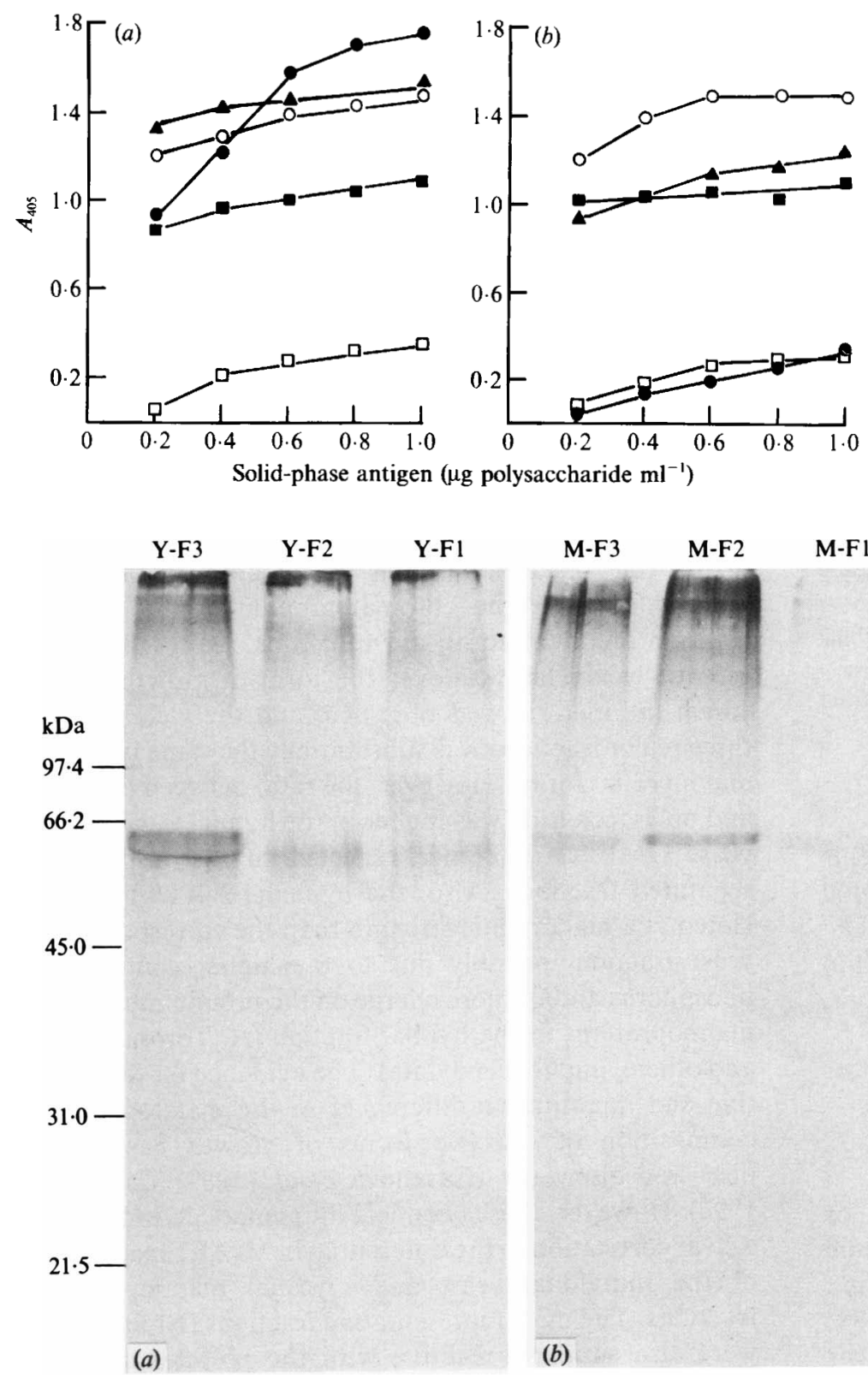

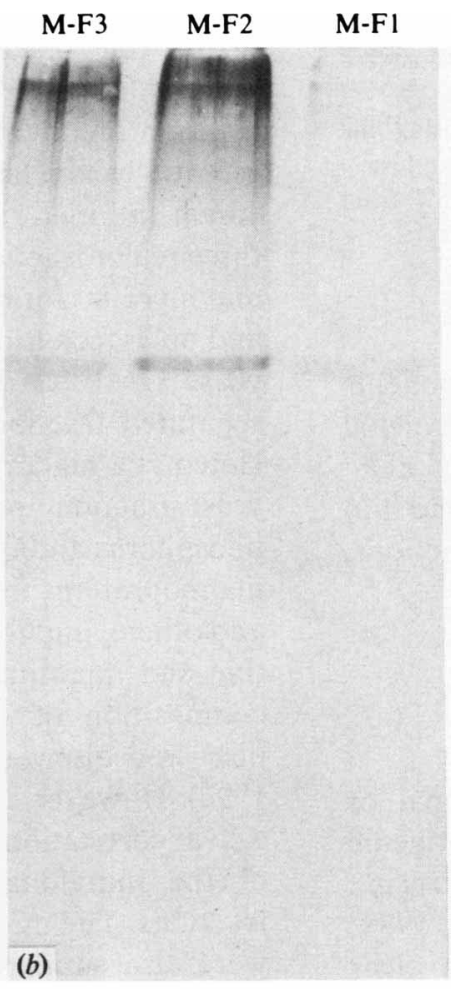

Fig. 3. mAb AF1 reactivity of individual GMP fractions from yeast $(a)$ and mycelial $(b)$ cells of $C$. albicans in ELISA using the indicated doses of each fraction as coating antigen. $\mathrm{O}, \mathrm{GMP} ; \boldsymbol{O}, \mathrm{F} 1 ; \mathbf{\Delta}, \mathrm{F} 2$; $\boldsymbol{D}, \mathrm{F} 3 ; \square, \mathrm{F} 4$. The values represent the mean of triplicate wells. For other details, see text.
Fig. 4. Immunoblotting, with $\mathrm{mAb} A F 1$, of mannoprotein fractions from yeast $(a)$ and mycelial $(b)$ cells of $C$. albicans. The positions of molecular mass standards are indicated. For other technical details, see text. apparently different intensity, all but fraction $\mathrm{F} 4$ from yeast cells strongly reacted with mAb AF1 (Fig. 3). Fractions $F 2$ and $F 3$ from the mycelial form also reacted strongly in ELISA with $\mathrm{mAb} A F 1$, although the F2 fraction was somewhat less reactive than the corresponding fraction from the yeast cells. In contrast, the mycelial fraction $F 1$ gave a very low reaction, similar to that of the $\mathrm{F} 4$ nucleoprotein fraction taken as negative control (Fig. 3). In other experiments, using high doses of coating antigens $(5.0 \mu \mathrm{g})$ and an inhibition-ELISA, it was confirmed that unlike the corresponding fraction from yeast cells, the $F 1$ fraction of mycelial cells, up to a concentration of $2 \mu \mathrm{g} \mathrm{ml}^{-1}$, did not appreciably react with mAb AF1 (data not shown).
The mannoprotein fractions were also reacted in ELISA with the polyclonal anti-Candida serum (Table 3). The data showed no reactivity differences between F1 and F2 fractions from yeast or mycelial cells. F4 was not recognized (or only very weakly so) by the polyclonal serum.

Attempts to check the specificity of the ELISA reaction and identify the molecular constituents recognized by $\mathrm{mAb}$ AF1 were also made. Fractions were run in a $5-10 \%$ acrylamide gradient gel, transblotted and reacted with $\mathrm{mAb} A F 1$. As shown in Fig. 4, in all $\mathrm{mAb}$ AF1-reactive fractions the antibody recognized an epitope carried by an electrophoretically heterogeneous, polydisperse material, mostly distributed in the region of 
Table 3. Indirect ELISA of yeast- and mycelial-derived GMP fractions with a polyclonal anti-Candida serum

\begin{tabular}{|c|c|c|c|}
\hline \multirow[b]{2}{*}{ Fraction } & \multirow[b]{2}{*}{ Dose* } & \multicolumn{2}{|c|}{$\begin{array}{l}\text { A }_{405} \dagger \text { using as } \\
\text { coating antigen: }\end{array}$} \\
\hline & & Y-GMP & M-GMP \\
\hline Control $\ddagger$ & $1 \cdot 0$ & \multicolumn{2}{|c|}{0.11} \\
\hline $\begin{array}{l}\text { Unfractionated } \\
\text { GMP }\end{array}$ & $\begin{array}{l}1 \cdot 0 \\
0 \cdot 2\end{array}$ & $\begin{array}{l}0.76 \\
0.45\end{array}$ & $\begin{array}{l}0.81 \\
0.54\end{array}$ \\
\hline F1 & $\begin{array}{l}1 \cdot 0 \\
0.2\end{array}$ & $\begin{array}{l}0.71 \\
0.39\end{array}$ & $\begin{array}{l}0.61 \\
0.34\end{array}$ \\
\hline $\mathrm{F} 2$ & $\begin{array}{l}1 \cdot 0 \\
0 \cdot 2\end{array}$ & $\begin{array}{l}0.81 \\
0.59\end{array}$ & $\begin{array}{l}0.83 \\
0.58\end{array}$ \\
\hline F3 & $\begin{array}{l}1 \cdot 0 \\
0 \cdot 2\end{array}$ & $\begin{array}{l}0.58 \\
0.39\end{array}$ & $\begin{array}{l}0.79 \\
0.57\end{array}$ \\
\hline F4 & $\begin{array}{l}1 \cdot 0 \\
0.2\end{array}$ & $\begin{array}{l}0 \cdot 17 \\
0 \cdot 20\end{array}$ & $\begin{array}{l}0 \cdot 20 \\
0 \cdot 16\end{array}$ \\
\hline
\end{tabular}

* Measured as $\mu \mathrm{g}$ polysaccharide $\mathrm{ml}^{-1}$.

$\dagger$ Values are the means of triplicate wells obtained using the indicated fraction as the solid-phase antigen at the indicated dose.

‡ A GMP fraction from C. parapsilosis, prepared as for GMP from C. albicans, was used as coating antigen, as a negative control.

high molecular mass components. These components were practically absent in the F1 fraction of the mycelial extract, which showed a faint band at around $65 \mathrm{kDa}$. This latter component, or a constituent very close to it in molecular mass, was also present in all other fractions, regardless of their yeast or mycelial source.

\section{Discussion}

Several recent studies performed with polyclonal or monoclonal reagents have emphasized the antigenic variability of the cell surface in C. albicans (Poulain et al., 1985; Brawner \& Cutler, 1987; Chaffin et al., 1988; Casanova et al., 1989). However, it is not yet clear whether, and to what extent, this variability affects molecules which are relevant in the host-parasite relationship in candidosis. In this study, we measured the reactivity of a monoclonal antibody (mAb AF1) with constituents of a mannoprotein extract that has previously been shown to modulate a number of specific and nonspecific immune responses in the experimental animal and in man (Cassone, 1990). Immunofluorescence showed that mAb AF1 binds extensively to the surface of yeast cells but scarcely, if at all, to that of the germtube $(4 \mathrm{~h})$ or hyphal $(24 \mathrm{~h})$ wall. This was verified with a number of fungal strains and hyphae induced in two media, and could not be accounted for solely by a decreased thickness of hyphal wall, as demonstrated by the fluorescence patterns observed with the polyclonal serum (Fig. 1 and other data, not shown). Interestingly, two agerminative variants of $C$. albicans exhibited strong binding of $\mathrm{mAb} A F 1$ to their surface at both $37^{\circ} \mathrm{C}$ and $28^{\circ} \mathrm{C}$, suggesting that the modulated expression of $\mathrm{mAb}$ AFl-reactive epitope did not merely depend on the temperature necessary for the development of each form. However, as in other instances of modulated epitope expression (Brawner \& Cutler, 1986; Chaffin et al., 1988), quantitative differences in binding of $\mathrm{mAb} A F 1$ to the yeast cell surface were detected, depending on the strain and also on growth conditions.

The results reported in this paper show that the oligosaccharide epitope recognized by $\mathrm{mAb} A F 1$ is shared by different chromatographically-separated mannoprotein fractions in the cell wall of $C$. albicans. Each fraction showed a heterogeneous distribution of mAb AF1 reactivity, much of which was of high molecular mass. The chromatographic profile of the mannoprotein extract in our reference strain (BP) was essentially similar whatever the form of growth from which the material was obtained, and the yield of the three major fractions was substantially the same in yeast and mycelial forms. However, the ratio between protein and polysaccharide was higher in the hyphal than in the yeast GMP, a difference reflected in the respective separated fractions. Also, the hyphal F2 fraction was eluted at a higher ionic strength than the corresponding yeast fraction, possibly due to the higher content of phosphorus and/or more charge on the protein moiety of mannoproteins in the hyphal fraction (A. Torosantucci and others, unpublished data). The evidence for qualitative and quantitative differences in the mannoprotein composition of the two forms of growth has been discussed elsewhere (Casanova et al., 1989; Cassone, 1990). However, these chemical differences do not show a clear correlation to the differential mAb AF1 reactivity of the individual yeast and mycelial mannoprotein fractions. The most representative fractions (F1 and F2) were also similarly reactive with the polyclonal antiCandida serum.

As two of the three mannoprotein constituents of the mycelial extract ( $F 2$ and $F 3$ ) reacted with $\mathrm{mAb} A F 1$, the lack or the greatly diminished expression of $\mathrm{mAb} A F 1$ reactive epitope on the surface of germ-tube and hyphal cells is not due to the absence of relevant epitope-bearing mannoproteins in this form of growth. The lack of expression, however, would be explained if the F1 constituent were the only or the predominant mannoprotein constituent expressed on the yeast cell surface. Alternatively, either F2 or F3 (or both) might also be expressed on the surface of the yeast form together with F1 but remain confined in the inner layers of the cell wall in the hyphal cell. Recent, preliminary experiments on mannoprotein localization by immunogold electron 
microscopic techniques have shown that mAb AF1reactive epitopes are present in both external and internal wall layers in the yeast form but almost exlusively in the inner wall layers of the mycelial form (J. P. Latgé, personal communication).

Chemical and ultrastructural studies have demonstrated the shedding of surface constituents early in germ-tube development (Cassone et al., 1973; Chattaway et al., 1974; Brawner \& Cutler, 1986), and we have recently observed that the released material contains mAb AF1-reactive, mannoprotein constituents, chromatographically similar to the $F 1$ and $F 2$ fractions reported here (A. Torosantucci and others, unpublished data). It could therefore be that some mAb AF1reactive mannoproteins are shed into the external medium during initiation of the hyphal transition, while those that are still synthesized are no longer exported to the cell surface during hyphal growth. Finally, in order to be detected by immunofluorescence, a single epitope might need to be arranged in an ordered structure, and/or with an elevated density, at the cell surface. Thus, a scattered/disorganized arrangement could result in unreactivity. The three possibilities considered above are not mutually exclusive.

The $\mathrm{F} 1$ and $\mathrm{F} 2$ mannoprotein fractions have recently been obtained in sufficient quantity to allow their immunomodulatory properties to be assayed in both experimental and human models. Only F2 retained those immunological activities possessed by the crude extract (GMP), such as the antigenic induction of $\mathrm{T}$-cell proliferation (Ausiello et al., 1986) and interferon production (Spagnoli et al., 1985; A. Torosantucci and others, unpublished data). In view of these properties, the lack or the greatly diminished expression of the F2 constituent from the hyphal cell surface may be relevant to the relationship between this form of growth and the pathogenicity of the fungus.

Thanks are due to B. Volpi for his excellent technical assistance and Mrs A. M. Marella for help in preparation of the manuscript. This work was supported in part by a grant from CNR (Italy), Special Project 'FATMA' and by ISS-Progetto Nazionale AIDS 88-89 (Unit 006).

\section{References}

Ausiello, C. M., Spagnoli, G. C., Boccanera, M., Casalinuovo, I., Malavasi, F., Casciani, C. U. \& Cassone, A. (1986). Proliferation of human peripheral blood mononuclear cells induced by Candida albicans and its cell wall fractions. Journal of Medical Microbiology 22, 195-202.

Ausiello, C. M., Palma, C., Spagnoli, G. C., Piazza, A., Casciani, C. U. \& CASSONE, A. (1989). Cytotoxic effectors in human peripheral blood mononuclear cells induced by a mannoprotein complex of Candida albicans: a comparison with interleukin 2-activated killer cells. Cellular Immunology 121, 349-359.
BRAWNER, D. L. \& CUTLER, J. E. (1986). Ultrastructural and biochemical studies of two dynamically expressed cell surface determinants on Candida albicans. Infection and Immunity 51, 327336.

BRAWNer, D. L. \& CUTLER, J. E. (1987). Cell surface and intracellular expression of two Candida albicans antigens during in vitro and in vivo growth. Microbial Pathogenesis 2, 249-257.

Casanova, M., Gil, M. L., Cardenoso, L., Martinez, J. P. \& SENTANDREU, R. (1989). Identification of wall-specific antigens synthesized during germ-tube formation by Candida albicans. Infection and Immunity 57, 262-271.

CASSONE, A. (1990). Cell wall of Candida albicans, its functions and its impact on the host. Current Topics in Medical Mycology 3, 249-314.

Cassone, A., Simonetti, N. \& Strippoli, V. (1973). Ultrastructural changes in the wall during germ-tube formation from blastospores of Candida albicans. Journal of General Microbiology 77, 417-423.

Cassone, A., Marconi, P. \& Bistoni, F. (1987). Cell wall of Candida albicans and host response. Critical Reviews in Microbiology 15, 87-98.

Cassone, A., Torosantucci, A., Boccanera, M., Pellegrini, G., Palma, C. \& Malavasi, F. (1988). Production and characterization of a monoclonal antibody to a cell surface, glucomannoprotein constituent of Candida albicans and other pathogenic Candida species. Journal of Medical Microbiology 27, 233-238.

Chaffin, W. L., SkudlareK, J. \& Morrow, K. J. (1988). Variable expression of a surface determinant during proliferation of Candida albicans. Infection and Immunity 56, 302-309.

Chattaway, F. W., Shenolikar, S. \& Barlow, A. J. E. (1974). The release of acid phosphatase and protein-containing components from the surface of the dimorphic forms of Candida albicans by treatment with dithiothreitol. Journal of General Microbiology 83, 423-429.

DOMER, J., Elkins, K., ENNIST, D. \& BAKer, P. (1988). Modulation of immune responses by surface polysaccharides of Candida albicans. Reviews of Infectious Diseases 105, 419-422.

Dubois, M., Gilles, K. A., Hamilton, J. K., Rebers, P. A. \& Smith, F. (1956). Colorimetric method for determination of sugars and related substances. Analytical Chemistry 28, 350-356.

LAEMMLI, U. K. (1970). Cleavage of structural proteins during the assembly of the head of bacteriophage T4. Nature, London 227, 680685 .

LeE, K. L., Buckley, H. R. \& Campbell, C. (1975). An amino acid liquid synthetic medium for the development of mycelial and yeast forms of Candida albicans. Sabouraudia 13, 148-153.

Mariani, M., Cianfriglia, M. \& Cassone, A. (1989). Is mouse IgM purification on protein A possible? Immunology Today 10, 115-116.

Mattia, E., Carruba, G., Angiolella, L. \& Cassone, A. (1982). Induction of germ-tube formation by $N$-acetyl-D-glucosamine in Candida albicans: uptake of inducer and germinative response. Journal of Bacteriology 152, 555-562.

Mondello, F., Guglielminetti, M., Torosantucci, A., Ceddia, T., Agatensi, L. \& Cassone, A. (1986). Yeast species isolated from outpatients with vulvovaginal candidosis attending a gynecological centre in Rome. ICRS Medical Sciences 14, 746-747.

ODDs, F. C. (1987), Candida infections: an overview. Critical Reviews in Microbiology 15, 1-6.

Poulain, D., Hopwood, V. \& Vernes, A. (1985). Antigenic variability of Candida albicans. Critical Reviews in Microbiology 12, 223-270.

Scaringi, L., Marconi, P., Boccanera, M., Tissi, L., Bistoni, F. \& CASsONe, A. (1988). Cell wall components of Candida albicans as immunomodulators: induction of natural killer and macrophage-mediated peritoneal cell cytotoxicity in mice by mannoprotein and glucan fractions. Journal of General Microbiology 134, $1265-1274$

SMaIL, E. H. \& Jones, J. M. (1984). Demonstration and solubilization of antigens expressed primarily on the surfaces of Candida albicans germ tubes. Infection and Immunity 45, 74-81.

Spagnoli, G., Ausiello, C. M., Casalinuovo, I., Antonelli, G., Dianzani, F. \& Cassone, A. (1985). Candida albicans and a phosphorylated glucomannan protein fraction of its cell wall induce production of immune interferon by human peripheral blood mononuclear cells. IRCS Medical Sciences 13, 1190-1191. 
Sundstrom, P. M., TAM, M. R., Nichols, E. J. \& KenNy, G. E. (1988). Antigenic differences in the surface mannoproteins of Candida albicans as revealed by monoclonal antibodies. Infection and Immunity 56, 601-606.
Torosantucci, A., Angiolella, L., Filesi, C. \& Cassone, A. (1984). Protein synthesis and amino acid pool during yeast-mycelial transition induced by $\mathrm{N}$-acetyl-D-glucosamine in Candida albicans. Journal of General Microbiology 130, 3285-3293. 